\title{
e-Society
}

\section{Chris Randall}

\section{Edition No: $\quad$ Social Trends 41}

Editor: Jen Beaumont

Office for National Statistics

\section{Social Trends 41}


ISSN 2040-1620

\section{A National Statistics publication}

National Statistics are produced to high professional standards set out in the Code of Practice for Official Statistics. They are produced free from political influence.

\section{About us}

\section{The Office for National Statistics}

The Office for National Statistics (ONS) is the executive office of the UK Statistics Authority, a non-ministerial department which reports directly to Parliament. ONS is the UK government's single largest statistical producer. It compiles information about the UK's society and economy, and provides the evidence-base for policy and decision-making, the allocation of resources, and public accountability. The DirectorGeneral of ONS reports directly to the National Statistician who is the Authority's Chief Executive and the Head of the Government Statistical Service.

\section{The Government Statistical Service}

The Government Statistical Service (GSS) is a network of professional statisticians and their staff operating both within the Office for National Statistics and across more than 30 other government departments and agencies.

\section{Contacts}

\section{This publication}

For information about the content of this publication, contact Jen Beaumont

Tel: 01633651622

Email: social.trends@ons.gsi.gov.uk

\section{Other customer enquiries}

ONS Customer Contact Centre

Tel: 08456013034

International: +44(0)8456013034

Minicom: 01633815044

Email: info@statistics.gsi.gov.uk

Fax: 01633652747

Post: Room 1.101, Government Buildings, Cardiff Road, Newport, South Wales NP10 8XG

www.ons.gov.uk

\section{Media enquiries}

Tel: 08456041858

Email: press.office@ons.gsi.gov.uk

\section{Copyright and reproduction}

(C) Crown copyright 2010

You may re-use this information (not including logos) free of charge in any format or medium, under the terms of the Open Government Licence.

To view this licence, go to:

http://www.nationalarchives.gov.uk/doc/opengovernment-licence/ or write to the Information Policy Team, The National Archives, Kew, London TW9 4DU email: psi@nationalarchives.gsi.gov.uk. 
This is the first Social Trends chapter to focus on e-Society. For most people, new technology plays a crucial part in their daily lives, from use of a computer and having Internet access at home or work, to texting or making calls on a mobile phone. Even if people do not make direct use of this technology, they are surrounded by networks through which information constantly flows. It allows anyone to create new information, provides convenient access to information and enables people to interact with information produced by others, especially on the Internet. Digital television and radio services allow a greater number of channels to be broadcast and allow viewers to interact with what they see and hear. People can take new technology with them virtually anywhere they go; computers can be portable and phones can be mobile.

\section{Key points:}

\section{Household access to the Internet}

- In 2010, 19.2 million households in the UK had Internet access, 73 per cent of households. This compares with 57 per cent in 2006, equivalent to 14.3 million households

- In the UK in 2008, over 8 in 10 (83 per cent) households with dependent children had Internet access

- In 2008, households in the highest 10 per cent of the income distribution in the UK were over three-and-a-half times as likely as those in the lowest 10 per cent to have an Internet connection, 96 per cent of households compared with 26 per cent

\section{Use of the Internet and other technologies}

- Just over a third (34 per cent) of adults aged 15 and over in the UK stated that they or someone else in their household had watched online television or videos in 2009

- Over three-quarters (78 per cent) of all those who had accessed the Internet in the three months prior to interview had done so every day or almost every day, while a fifth (17 per cent) had accessed it at least once a week but not every day

\section{Online communication and social networking}

- The proportion of Internet users in the UK aged 16 and over who had their own social networking site profile doubled between 2007 and 2009, from 22 per cent to 44 per cent

\section{Children's use of new technology}

- Just over a quarter (27 per cent) of children aged 5 to 15 owning a mobile phone in 2009 in the UK had first acquired one by the time they were eight years old and just under two-thirds (65 per cent) by the time they were 10 years old

- Nearly 3 in 10 (59 per cent) parents and guardians of those aged 6 to 17 in the UK were very or rather worried that their child might see sexually or violently explicit images on the Internet, while 46 per cent were very or rather worried that their child could become a victim of online grooming 


\section{New technology in education and work}

- The number of users of computers with Internet access in the workplace in the UK increased by 27 per cent between 2004 and 2008, from the equivalent to 5.9 million employees in 2004 to 7.5 million in 2008

\section{e-commerce and online banking}

- Among EU-27 member states, the use of the Internet to order goods and services was most common in the UK: in 2009, 66 per cent of adults aged 16 to 74 in the UK had done so in the 12 months prior to interview

- Losses through online banking fraud largely due to malware which targets vulnerabilities in customers' PCs, rather than the banks' own systems totalled $£ 59.7$ million in the UK in 2009

\section{e-government}

- 46 per cent of adults aged 16 and over in the UK who had accessed the Internet in the 12 months prior to interview had obtained information from a public authority website in 2010 


\title{
Household access to the Internet
}

\section{Figure $1 \quad$ Household Internet access}

\author{
United Kingdom
}

Percentages

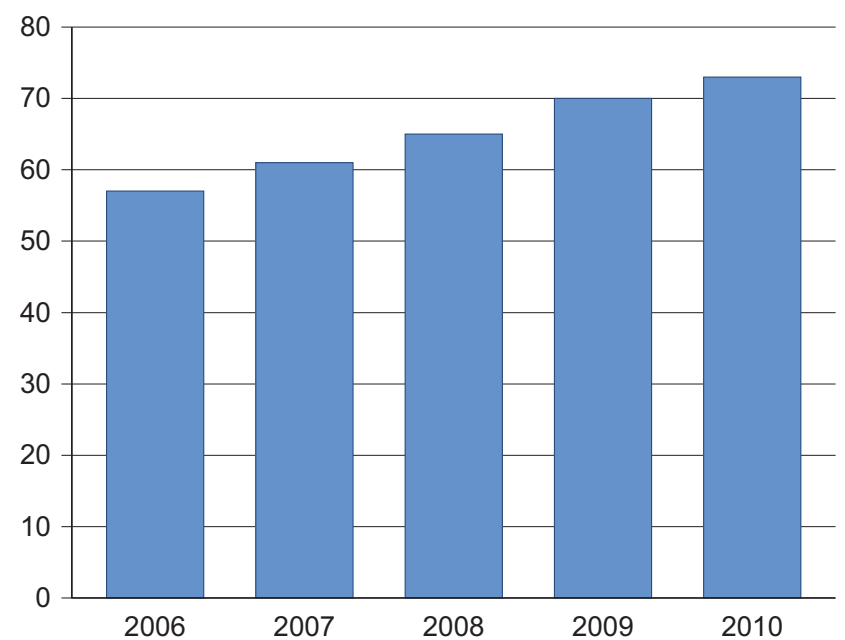

Source: Opinions Survey, (ONS, 2010)

The proportion of households with Internet access at home has been increasing year on year (Figure 1). In 2010, 19.2 million households in the UK had Internet access, 73 per cent of households. This compares with 57 per cent in 2006, equivalent to 14.3 million households. Internet access varied between the UK regions in 2010, with the highest levels of access in London at 83 per cent and the South East at 79 per cent. The lowest levels of Internet access were in the North East at 59 per cent and Scotland at 64 per cent (ONS, 2010).

Access to new technology and particularly the Internet is not universal. The gap between those who can access the Internet and other information communication technologies (ICTs) and those who cannot is often referred to as the 'digital divide'. Adults without an Internet connection at home are more likely to be older (particularly those over retirement age), have no formal educational qualifications or have lower annual household incomes (ONS, 2010).

According to the ONS Living Costs and Food Survey, in the UK in 2008 more than 8 in 10 (83 per cent) of households with dependent children ${ }^{i}$ had Internet access. Households consisting of a couple with children were the most likely of all types of household to have access in 2008 (88 per cent), while lone parent households were the least likely of all households with children to have Internet access (63 per cent). Older households were the least likely to have Internet access. Fewer than 4 in 10 (37 per cent) of one person households over state pension age had Internet access in 2008 compared with just under 8 in 10 (79 per cent) of one person households under state pension age.

According to the same survey, rates of Internet access rose for all types of households in the UK between 2000-01 and 2008. For most types of households, the proportion with Internet access rose 
by about 40 percentage points over the period. However, the increase was only 26 percentage points for one person households over state pension age.

According to the ONS Opinion Survey, in 2009, just under two-thirds (63 per cent) of households, equivalent to 16.5 million households, had broadband Internet access ${ }^{\text {ii. }}$. This was an increase of 6.6 million households since 2006. The proportion of UK households with a dial up connection fell by 10 percentage points between 2006 and 2009 to reach 7 per cent, equivalent to 1.8 million households. Nine in 10 households (90 per cent) with Internet access had a broadband connection in 2009, an increase from 69 per cent in 2006 (ONS, 2009a)

\section{Table $1 \quad$ Households with broadband connection: ${ }^{1}$ EU comparison, 2009}

\begin{tabular}{lllr} 
& & & Percenta \\
\hline Top 6 countries & & Bottom 6 countries & 46 \\
\hline Sweden & 79 & Portugal & 42 \\
Netherlands & 77 & Slovakia & 39 \\
Denmark & 76 & Italy & 33 \\
Finland & 74 & Greece & 26 \\
Luxembourg & 71 & Bulgaria & 24 \\
United Kingdom & 69 & Romania &
\end{tabular}

EU-27 average

56

1 Proportion of households with broadband access with at least one member aged 16 to 74 .

Source: Eurostat (table isoc_pibi_hba)

Broadband access also varies across the EU. In 2009 Sweden ranked highest, with 79 per cent of households having broadband access, while the UK ranked sixth, at 69 per cent which was 13 percentage points above the EU-27 average (Table 1). Romania ranked the lowest with less than a quarter of households having a broadband connection (24 per cent), 32 percentage points lower than the EU-27 average.

In all EU-27 countries broadband access increased substantially between 2006 and 2009 . The percentage of households in Romania with a broadband connection increased by 19 percentage points, from 5 per cent to 24 per cent but the largest increase among countries ranked in the bottom six was recorded by Slovakia, increasing 31 percentage points from 11 per cent in 2006 . Within the top six countries, the largest increase was seen in Sweden, 28 percentage points since 2006 (Eurostat table isoc_pibi_hba). 


\section{Table 2}

\section{Household ownership of selected new technology: by income group, ${ }^{1} 2008$}

United Kingdom

Percentages

\begin{tabular}{lrrrr}
\hline & Internet connection & Mobile phone & Satellite receiver $^{2}$ & Home computer \\
\hline Lowest decile group & 26 & 61 & 63 & 33 \\
2nd & 33 & 62 & 73 & 42 \\
3rd & 40 & 66 & 74 & 47 \\
4th & 54 & 77 & 82 & 65 \\
5th & 68 & 83 & 86 & 75 \\
6th & 76 & 86 & 86 & 83 \\
7th & 85 & 87 & 88 & 91 \\
8th & 88 & 87 & 91 & 93 \\
9th & 94 & 89 & 92 & 95 \\
Highest & 96 & 89 & 91 & 98 \\
\hline
\end{tabular}

1 Households are ranked according to their income and then divided into 10 groups of equal size. The lowest decile group is the 10 per cent of households with the lowest incomes.

2 Digital television service. Includes digital and cable receivers.

Source: Living Costs and Food Survey (ONS, 2009b)

There is a relationship between ownership of new technology and household income. Household ownership of home computers and Internet access increase considerably as household income increases. In 2008 households in the highest 10th of the income distribution (the highest decile group were over three-and-a-half times as likely as those in the lowest 10 per cent to have an Internet connection, 96 per cent of households compared with 26 per cent (Table 2). They were also nearly three times likely to own a home computer, 98 per cent compared with 33 per cent. Household ownership of mobile phones and a digital television service in the UK are also linked to income, although to a lesser extent. Households in the highest income group were nearly one-anda-half times more likely to have a satellite receiver or a mobile phone than those in the lowest income group. 


\section{Figure 2 Reasons why households do not have Internet access ${ }^{1}$}

United Kingdom

Percentages

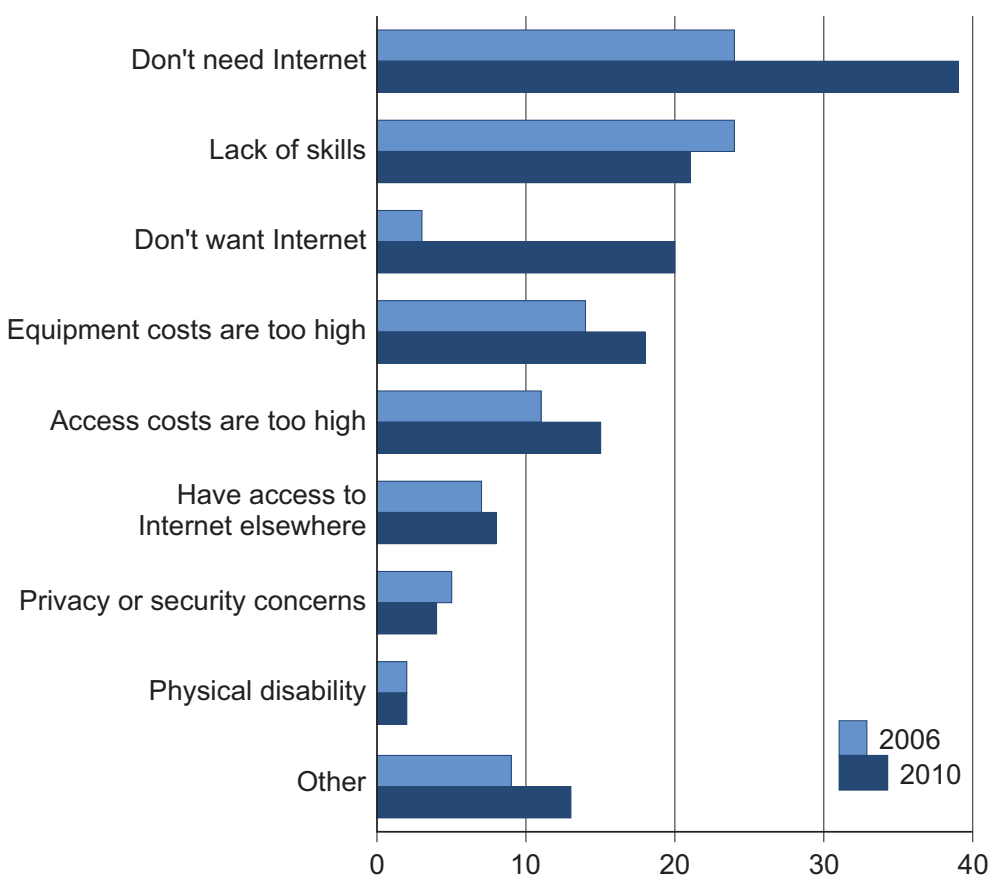

1. Respondents were asked 'What are the reasons for not having access to the Internet at home?'

Source: Opinions Survey, (ONS, 2006, 2010)

There are many possible reasons why households in the UK do not have access to the Internet. Not having a need for access was the most common reason reported in 2010 at 39 per cent, an increase of 15 percentage points since 2006 (Figure 2). Just over a fifth (21 per cent) of households did not have access because of a lack of skills in the household, a fall of 3 percentage points since 2006. A fifth (20 per cent) of households with no access simply did not want the Internet, a rise of 17 percentage points since 2006.

\section{Use of the Internet and other technologies}

According to Ofcom, people who used new technology in 2010 in the UK spent almost half (45 per cent) of their waking hours watching television, using their mobiles and other communication devices such as the Internet (Ofcom, 2010a). Given this intensity of use, in 2009 Ofcom asked adults aged 16 and over which media activity they would miss doing the most. 


\section{Table $3 \quad$ Media activities that would be missed most: by age group, ${ }^{1} 2009$}

United Kingdom

Percentages

\begin{tabular}{|c|c|c|c|c|c|c|c|}
\hline & $16-24$ & $25-34$ & $35-44$ & $45-54$ & $55-64$ & 65 and over & $\begin{array}{r}\text { All aged } \\
16 \text { and } \\
\text { over }\end{array}$ \\
\hline Television & 36 & 47 & 52 & 49 & 57 & 60 & 50 \\
\hline Internet & 18 & 20 & 19 & 17 & 12 & 3 & 15 \\
\hline Mobile phone & 32 & 14 & 9 & 7 & 4 & 1 & 11 \\
\hline Radio & 2 & 3 & 7 & 10 & 16 & 18 & 9 \\
\hline Newspapers or magazines & 1 & 2 & 3 & 3 & 4 & 11 & 4 \\
\hline Other $^{2}$ & 11 & 14 & 10 & 14 & 7 & 7 & 11 \\
\hline
\end{tabular}

1 Respondents were asked 'Which one of these would you miss doing the most?'

2 Other includes listening to music on a hi-fi, CD or tape player, playing console or computer games, listening to portable music devices or an MP3 player, watching videos DVDs or using a portable media player.

Source: UK Adults' Media Literacy (Ofcom, 2010b)

In each age group, watching television would be the most missed media activity (Table 3 ). However, there are differences according to age. Adults aged 16 to 24 were less likely than older age groups to miss watching the television (36 per cent compared with 57 per cent and 60 per cent of the two oldest age groups shown). Nearly a third (32 per cent) of those aged 16 to 24 stated that they would miss using a mobile phone the most, compared with 14 per cent of those aged 25 to 34 and only 1 per cent of those aged 65 and over. The Internet would be missed by around a fifth of each age group among those aged 16 to 54. People aged 65 and over were more likely to miss more traditional media activities such as listening to the radio or reading newspapers and magazines.

The mobile phone is an increasingly powerful portable media device that allows people to undertake a wide range of activities. Beyond making voice calls, over 8 in 10 of adults ( 83 per cent) aged 15 and over in the UK used their mobile phone to send text messages and 56 per cent used it for voice mail in 2009 (Ofcom 2009c). The only other function used by more than half (52 per cent) of mobile phone users is taking and storing photos. The next most common use was picture messaging, performed by just over a quarter (27 per cent) of mobile phone users, while 19 per cent used their mobile phone to either listen to radio, MP3s or podcasts or used it as a personal organiser.

Digital convergence is a term used to describe the growing tendency for different content formats such as audio, video, text or pictures to reach consumers via a range of digital networks such as a computer, television or mobile phone $\mathrm{e}^{\mathrm{iii}}$. In 2009, just over a third (34 per cent) of adults aged 15 and over in the UK stated that they or someone else in their household had watched online television or videos (Ofcom, 2009b). Three in 10 (30 per cent) stated that they or someone else in their household had used the Internet to access a social networking site. Two in 10 (20 per cent) stated that they had used a mobile phone to access the Internet, a similar proportion (17 per cent) listened 
to audio content on their mobile phone, and 12 per cent stated that they or someone else in their household made voice calls or listened to the radio over the Internet.

In 2010, just under a fifth of adults (18 per cent) had never used the Internet; however, this differed by educational qualifications. Over half ( 55 per cent) of adults aged 16 and over in the UK with no qualifications had never used the Internet. In comparison only 2 per cent of adults with a degree or equivalent qualification had never used the Internet (ONS, 2010). When interviewed in 2010, just over three-quarters (77 per cent) of the UK population aged 16 and over had accessed the Internet in the three months prior to interview. Level of Internet use varies by the age of the user. Those aged 16 to 24 had the highest level of use, with 97 per cent using it within the three months prior to interview, compared with just under a third (32 per cent) of those aged 65 and over (ONS, 2010).

\section{Figure $3 \quad$ Frequency of Internet use: ${ }^{1}$ by age group, 2010}

United Kingdom

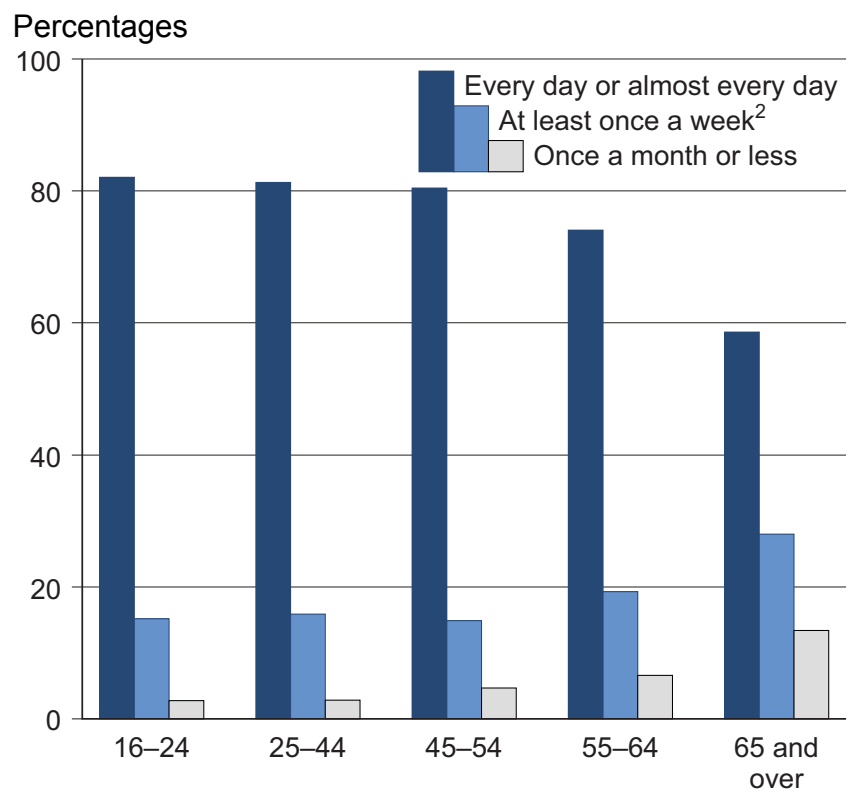

1 UK adults who have used the Internet in the three months prior to interview.

2 Not every day

Source: Opinions Survey (ONS, 2010)

Over three-quarters (78 per cent) of all those who had accessed the Internet in the three months prior to interview had done so every day or almost every day, while a fifth (17 per cent) had accessed it at least once a week but not every day. The proportion of those using the Internet every day or almost every day decreases with age. Those aged 16 to 24 accessed the Internet the most, with 82 per cent using it every day or almost every day (Figure 3). Internet users aged 65 and over used it the least, with just under 6 in 10 (59 per cent) using it every day or almost every day.

There are also geographical differences in Internet use across the UK. In 2010 just under 3 in 10 adults (29 per cent) aged 16 and over in the North East had never used the Internet, followed by around a fifth of adults in Scotland (22 per cent), Yorkshire and the Humber (21 per cent) and West Midlands (20 per cent). Only 13 per cent of adults in London had never used the Internet (ONS, 2010). 


\section{Table $4 \quad$ Selected activities performed on the Internet: ${ }^{1}$ by sex, 2010}

United Kingdom

Percentages

\begin{tabular}{|c|c|c|c|}
\hline & Men & Women & All \\
\hline Sending/receiving emails & 90 & 89 & 90 \\
\hline Finding information about goods and services & 77 & 73 & 75 \\
\hline Using services related to travel and accommodation & 64 & 63 & 63 \\
\hline Internet banking & 57 & 51 & 54 \\
\hline Reading or downloading online news, newspapers, magazines & 56 & 46 & 51 \\
\hline Listening to web radio or watching web television & 52 & 39 & 45 \\
\hline Posting messages to chat sites, blogs, newsgroups etc. & 44 & 42 & 43 \\
\hline Playing or downloading games, images, films or music & 45 & 34 & 40 \\
\hline Seeking health related information & 34 & 44 & 39 \\
\hline Uploading self created content & 36 & 40 & 38 \\
\hline Consulting the Internet with the purpose of learning & 39 & 31 & 35 \\
\hline Looking for information about education, training or courses & 30 & 33 & 32 \\
\hline Downloading software & 41 & 19 & 30 \\
\hline Looking for a job or sending a job application & 28 & 24 & 26 \\
\hline Telephoning over the Internet/video calls (via webcam) & 27 & 20 & 23 \\
\hline Selling goods or services over the Internet & 25 & 17 & 21 \\
\hline
\end{tabular}

1 Adults aged 16 and over who had accessed the Internet in the three months prior to interview.

Source: Opinions Survey (ONS, 2010)

The Internet is used for a range of activities. The most common activity in 2010 was sending or receiving emails by 9 in 10 adults (90 per cent) aged 16 and over in the UK in 2010 who had used the Internet in the three months prior to interview (Table 4). This was also the most common activity for both men and women (90 per cent of men and 89 per cent of women) who had used the Internet in the three months prior to interview.

Three-quarters of adults (75 per cent) used the Internet to find information about goods and services and 63 per cent used services related to travel and accommodation. Men were more likely than women to download software (41 per cent of men compared with 19 per cent of women) or to listen to web radio or watch web television (52 per cent compared with 39 per cent). Women were more likely than men to seek health related information (44 per cent of women compared with 34 per cent of men).

\section{Online communication and social networking}

The increase in popularity of modern technologies such as mobile phones and the Internet has changed the way that people communicate with each other. Online communication tools such as 
telephone calls over the Internet, video calls via webcams, social networking sites, email and instant messaging play an increasing role in how people keep in touch with existing friends and family and make new acquaintances.

Social networking sites offer new and varied ways to communicate via the Internet, whether through computers or mobile phones. Users can communicate via their 'profile' both with a list of contacts over which they have control - their 'friends' - and with others, either on a one-to-one basis through messages similar to emails, or in a more public way such as a comment posted for all to see.

\section{Figure $4 \quad$ People who have set up own social networking site profile: ${ }^{1}$ by age}

United Kingdom

Percentages

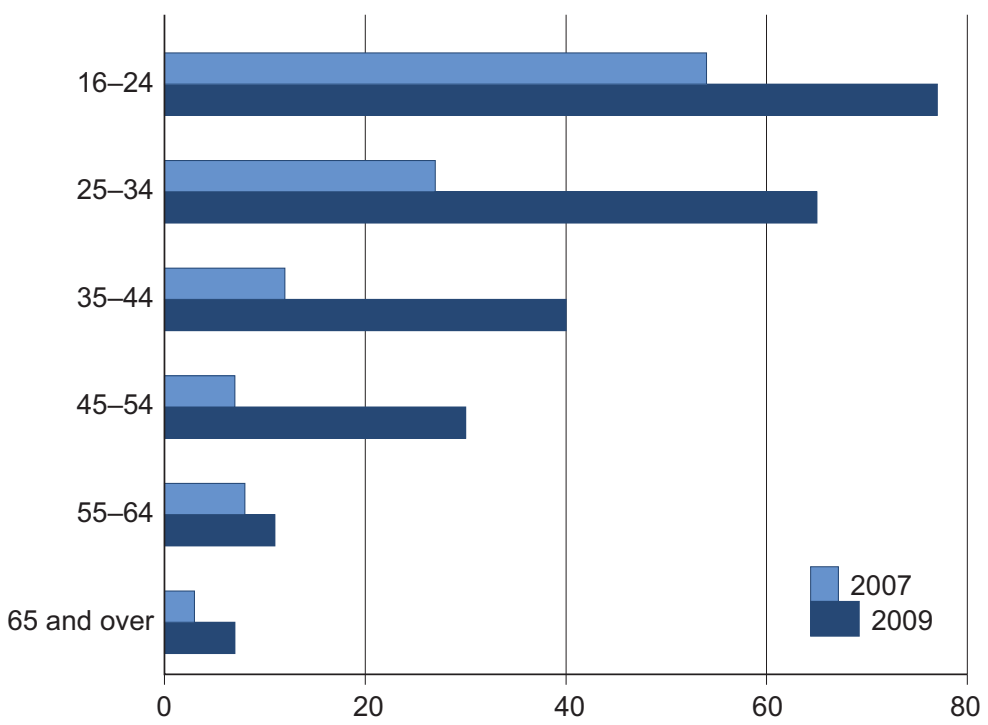

1 Profiles are a representation of each user often containing personal information such as their name, email address, phone number and photographs.

Source: UK Adults' Media Literacy (Ofcom, 2010b)

According to Ofcom, the proportion of Internet users in the UK aged 16 and over who had their own social networking site profile doubled between 2007 and 2009, from 22 per cent to 44 per cent. The proportion rose for all age groups but the largest rises were among those aged 25 to 34 (38 percentage points) and those aged 35 to 44 (28 percentage points) (Figure 4). Women were more likely than men to have set up a social networking site profile (48 per cent compared with 40 per cent in 2009).

Users of social networking sites reported that they used them to talk to friends and family they see a lot (78 per cent), those they rarely see (75 per cent), and to look for old friends and people they have lost contact with (47 per cent) (Ofcom, 2010b). In 2009, just under half of all Internet users in the UK said that using the Internet had increased the contact they have with friends (49 per cent) or family (47 per cent) who live further away. Lower proportions stated that their contact with friends (24 per cent) or family (18 per cent) who live nearby had increased. Just over one in five Internet users said that they had increased contact with people with whom they share personal interests and 
hobbies (22 per cent), and around 1 in 10 had increased contact with people with different interests and hobbies (11 per cent).

Social networking site users can manage the security settings of their profiles to control who can see their pages and the information contained on them. Many profiles can be limited so that only a user's 'friends' are allowed to see their profile pages. The use of such controls has grown: in 2009, 80 per cent of social networking site users in the UK had a profile that could be seen only by their friends, compared with 48 per cent in 2007 . The proportion of users with open profiles, that could be seen by anyone, fell from 44 per cent in 2007 to 17 per cent in 2009 (Ofcom, 2010b). This seems to indicate that social networking users are becoming more security conscious. See also Internet security.

Although many Internet users use online communication to keep in touch with existing friends and family, they may also use the Internet as a means to meet new people.

\section{Figure $5 \quad$ Internet users ${ }^{1}$ who met people online: by place met, 2009}

Great Britain

Percentages

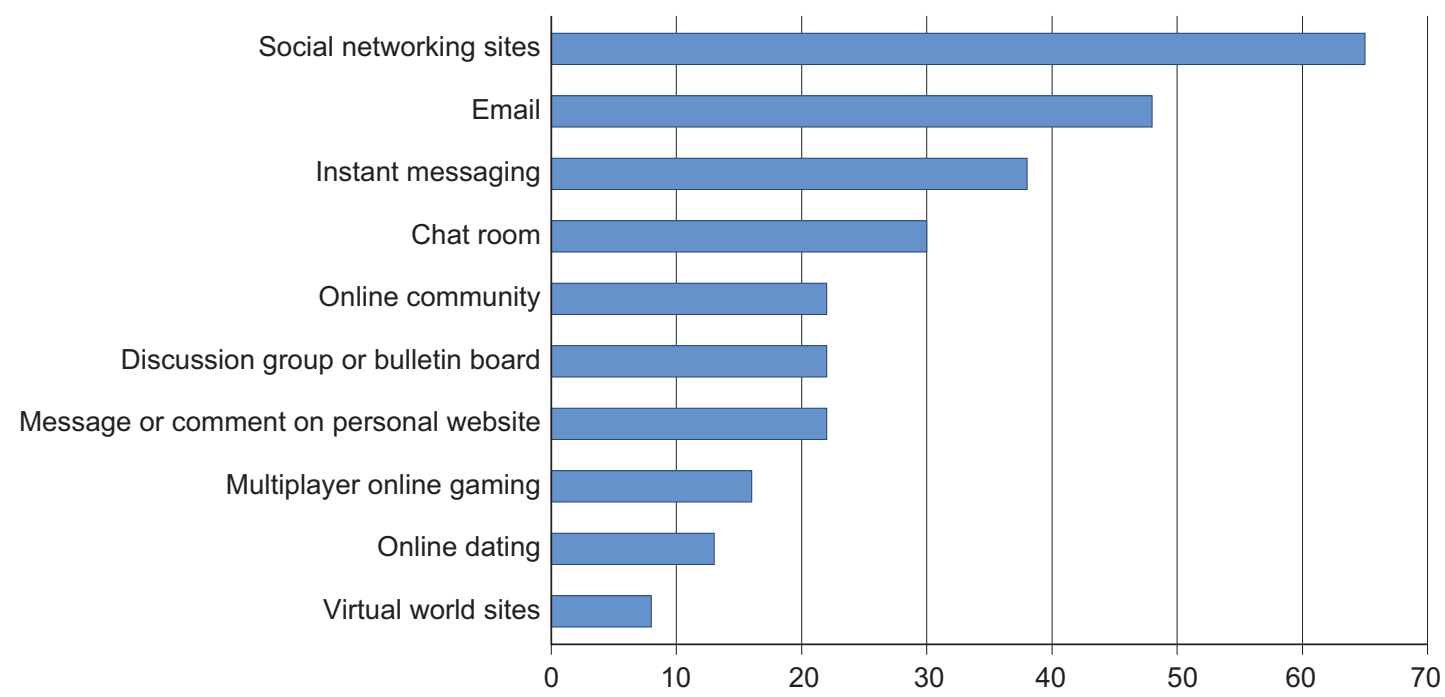

1 Current Internet users aged 14 and over who met people online.

Source: Oxford Internet Survey, (Dutton, Helsper and Gerber, 2009)

According to the 2009 Oxford Internet Survey the most common place for Internet users aged 14 and over in Great Britain to meet others online was social networking sites (with 65 per cent of people who met people online meeting them through social networking sites) (Figure 5). This was followed by email (48 per cent), instant messaging (38 per cent) and chat rooms (30 per cent). Just over a fifth of those who met someone online met them through comments on personal websites or online communities or discussion groups or bulletin boards all at 22 per cent. 


\section{Internet security}

Some Internet users may have unfavourable experiences online. For example, Internet security can be compromised in a variety of ways. According to the ONS Opinions Survey, in 2010 over half (54 per cent) of those aged 16 and over in the UK who had accessed the Internet in the 12 months prior to interview, had received unsolicited emails (also known as spam or junk mail) (ONS, 2010). These are often of a commercial nature, sent indiscriminately to multiple mailing lists, individuals, or newsgroups. Just over 3 in 10 Internet users (31 per cent) had caught a virus or other infection on their computer resulting in loss of information or time, and 5 per cent had experienced financial losses due to fraud when using a payment card. Abuse of personal information sent on the Internet and/or other privacy violations was relatively rare, having been experienced by 4 per cent. Financial losses as a result of responding to fraudulent messages (phishing) ${ }^{\mathrm{iv}}$ or being redirected to a fake site and providing personal information was experienced by 3 per cent. Two per cent of users reported that children had accessed inappropriate websites or had been connecting with potentially dangerous people from a computer in the household.

To overcome some of these security problems many people use some kind of security software or tool. In 2010, 85 per cent of UK adults who had used some sort of security software in the 12 months prior to interview had used a virus checking program or anti-spy ware program. Other common forms of security were hardware or software firewalls, used by 63 per cent, and email filtering to prevent spam used by 45 per cent (ONS, 2010).

Entering personal details online can be problematic since it may lead to unauthorised access to sensitive information such as usernames, passwords, Internet banking logons and credit card details which may then be used fraudulently. As knowledge about the potential risks of the Internet grows, there are an increasing number of users taking more care over Internet security. 


\section{Figure 6}

\section{Internet users who would be happy to enter personal details online: by type of details ${ }^{1}$}

United Kingdom

Percentages

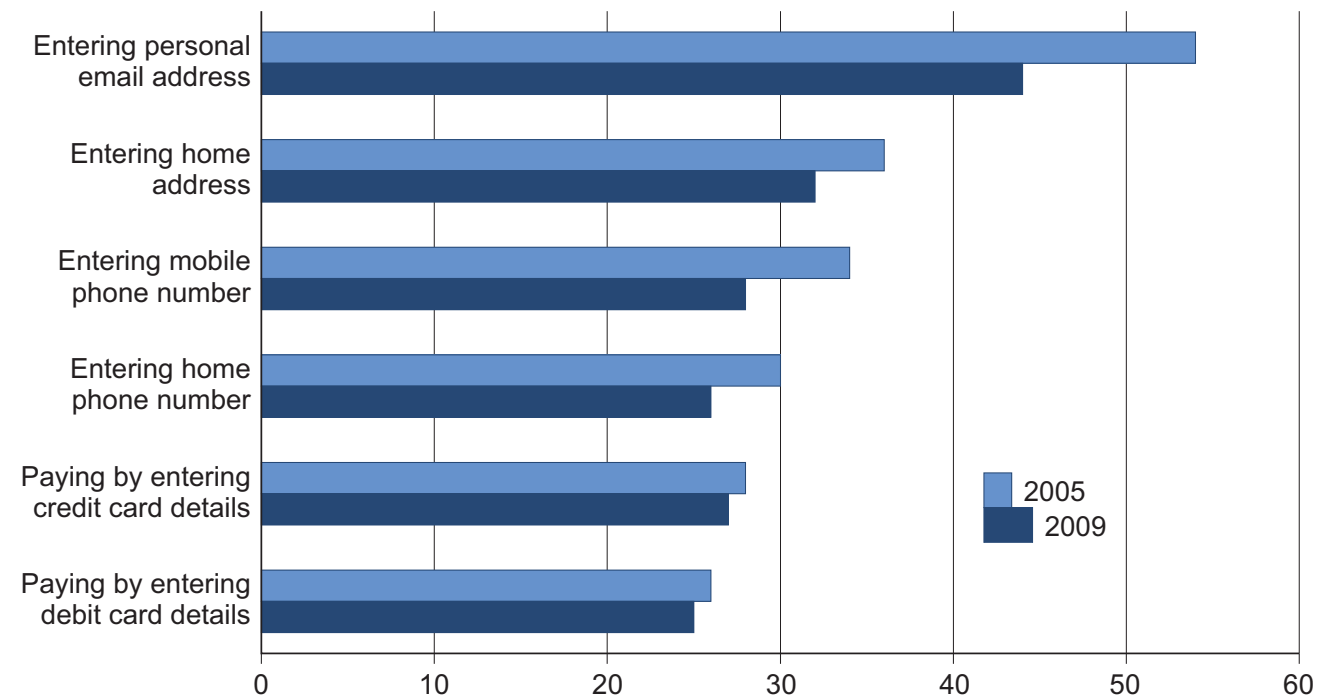

1 Internet users aged 16 and over and stated that they would be happy to do this when asked 'I'm going to read out some types of information you could be asked to enter when you're on the internet, and for each one l'd like you to say how you would feel about doing this in terms of any security concerns'.

Source: UK Adults' 'Media Literacy (Ofcom 2010b)

People are becoming more concerned about providing personal information online. Between 2005 and 2009 the proportion of UK Internet users aged 16 and over who were happy to provide six main types of personal information fell (Figure 6). Less than half (44 per cent) of respondents in 2009 said they would be happy to provide their personal email address compared with 54 per cent in 2005. Those willing to provide their home address decreased from 36 per cent to 32 per cent over the same period. Those happy to enter credit card or debit card details remained at around the same level in both years at around 27 per cent and 25 per cent respectively.

\section{Children's use of new technology}

Adults in older age groups are known as 'digital immigrants' as they grew up without digital technology and adopted it later. However, children under 16 are 'digital natives', since digital technology already existed when they were born, and hence they have grown up with it around them. According to Ofcom, around 9 in 10 (92 per cent) children aged 5 to 15 live in a household with a digital television service. Four in five (82 per cent) children aged 5 to 15 live in a household with access to the Internet through a home computer and 9 in 10 children aged 5 to 15 (89 per cent) live in a household with a games console (Ofcom, 2010c). 


\section{Figure $7 \quad$ Age at which child first acquired a mobile phone, ${ }^{1} 2009$}

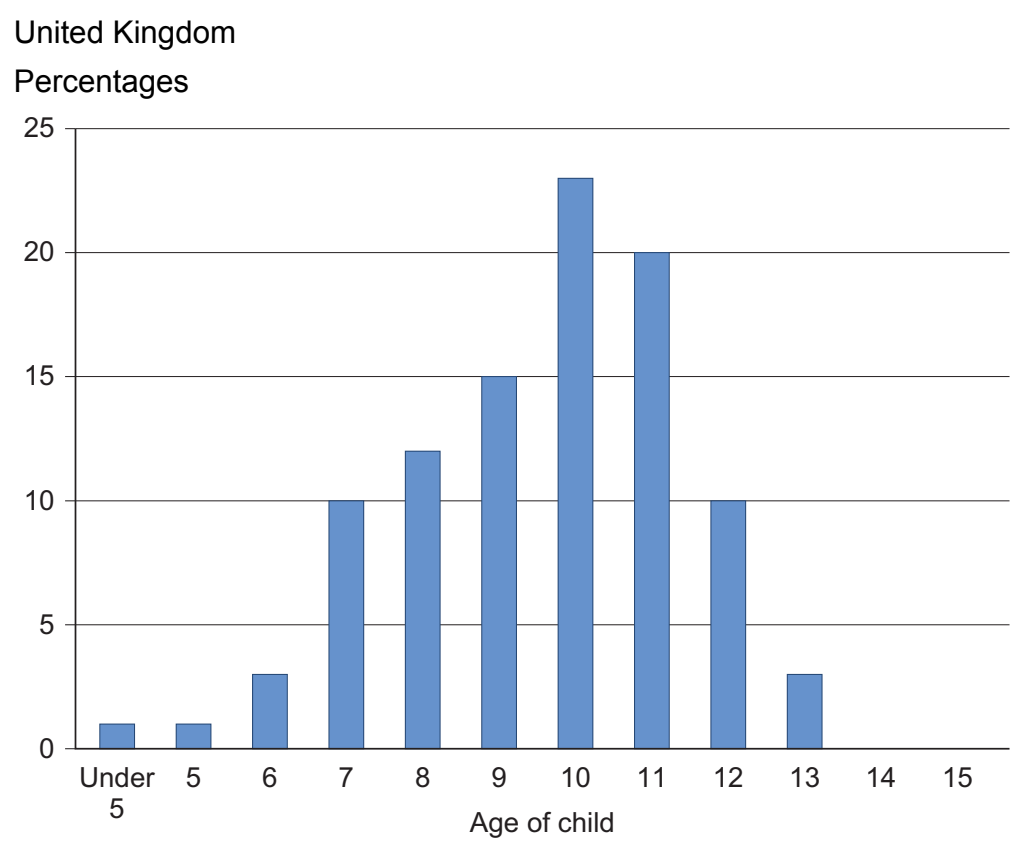

1 Parents of children aged 5 to 15 with a mobile phone were asked the question ' How old was your child when they first got a mobile phone that makes and receives calls?'

Source: UK Children's Media Literacy (Ofcom, 2010c)

Personal ownership of a mobile phone increases with age. In 2009 just under 1 in 10 (9 per cent) children aged 5 to 7 owned a mobile phone compared with 50 per cent of those aged 8 to 11 and 88 per cent of those aged 12 to 15 (Ofcom,2010c). Just over a quarter (27 per cent) of children aged 5 to 15 owning a mobile phone in 2009 had first acquired one by the time they were eight years old and just under two-thirds (65 per cent) by the time they were 10 years old (Figure 7). Girls were more likely than boys to have a mobile phone by the time they are 10 years old (68 per cent of girls compared with 61 per cent of boys). 


\section{Table 5 Main reasons for children's dislikes of selected ICTs: ${ }^{1}$ by age group, 2009}

United Kingdom Percentages

\begin{tabular}{|c|c|c|}
\hline & 8-11 & $12-15$ \\
\hline \multicolumn{3}{|l|}{ Internet } \\
\hline Websites that take too long to load & 36 & 42 \\
\hline Too many adverts & 16 & 23 \\
\hline \multicolumn{3}{|l|}{ Mobile phone } \\
\hline It costs too much money & 36 & 49 \\
\hline People can send hurtful messages to other people & 12 & 15 \\
\hline Sometimes people get bullied on them & 13 & 14 \\
\hline \multicolumn{3}{|l|}{ Online gaming } \\
\hline Sometimes spend too much time on them & 19 & 34 \\
\hline Someone might pretend to be my age and get to know me & 15 & 16 \\
\hline Strangers might find out information about me & 14 & 16 \\
\hline
\end{tabular}

1 Children aged 8 to 15 were shown a list of dislikes and asked if any of them related to their use of the media shown in the table.

Source: UK Children's Media Literacy (Ofcom, 2010c)

New technologies are perceived to have drawbacks as well as advantages. Children aged 8 to 15 who used the Internet, watched television, used a mobile phone or played games over the Internet were prompted with a list of dislikes and were asked if any of them applied to them. Children aged 8 to 11 and 12 to 15 were most likely to state that 'websites take too long to load' (36 per cent and 42 per cent respectively) and that there were 'too many adverts' on the Internet (16 per cent and 23 per cent respectively) (Table 5).

Cost issues were the main drawback associated with mobile phones, with over a third (36 per cent) of those aged 8 to 11 and just under a half (49 per cent) of those aged 12 to 15 agreeing that mobile phones 'cost too much money'. 'Spending too much time' was the most common drawback identified by just under a fifth (19 per cent) of those aged 8 to 11 and just over a third (34 per cent) of those aged 12 to 15 who played games over the Internet. Around 14 to 16 per cent of users of the Internet among both age groups of felt that 'someone might pretend to be my age and get to know me' or 'strangers might find out information about me' as things they did not like about online gaming (Ofcom, 2010c). For more information on children's use of new technology see also Social Networking and New technology in education and work. 


\section{Table 6 Parents' concerns ${ }^{1}$ about online risks, 2008}

\begin{tabular}{|c|c|c|c|c|c|}
\hline & $\begin{array}{r}\text { Very } \\
\text { much } \\
\text { worried }\end{array}$ & $\begin{array}{l}\text { Rather R } \\
\text { worried }\end{array}$ & $\begin{array}{l}\text { ather not } \\
\text { worried }\end{array}$ & $\begin{array}{l}\text { Not at all } \\
\text { worried a }\end{array}$ & $\begin{array}{r}\text { Don't } \\
\text { know/Not } \\
\text { applicable }\end{array}$ \\
\hline Might see sexually/violently explicit images on the Internet & 37.4 & 21.4 & 13.4 & 27.4 & 0.4 \\
\hline Might be a victim of online grooming ${ }^{2}$ & 32.2 & 14.2 & 11.2 & 41.2 & 1.2 \\
\hline Might get information about self-harm, suicide, anorexia & 25.8 & 16.2 & 10.4 & 46.2 & 1.4 \\
\hline Might see sexually/violently explicit images via the mobile phone & 25.8 & 10.4 & 9.4 & 42.2 & 12.2 \\
\hline Could be bullied online by other children & 24.2 & 15.2 & 16.6 & 42.6 & 1.4 \\
\hline Could be bullied by other children via the mobile phone & 23.8 & 13.4 & 9.4 & 39.8 & 13.6 \\
\hline $\begin{array}{l}\text { Might become isolated from other people if spending too much } \\
\text { time online }\end{array}$ & 21.2 & 19.6 & 10.2 & 48.4 & 0.6 \\
\hline May give out personal/private information online & 16.4 & 17.0 & 24.0 & 42.2 & 0.4 \\
\hline
\end{tabular}

1 Parents or guardians of children aged 6 to 17 were asked the question 'How worried are you that when your child is using the Internet or mobile phone, he/she might...'

2 Child grooming is the deliberate actions taken by an adult to form a trusting relationship with a child, with the intent of later having sexual contact.

Source: Flash Eurobarometer 248 (European Commission, 2008)

Parents are particularly concerned about their children using the Internet or a mobile phone.

According to a Flash Eurobarometer ${ }^{v}$ report in 2008, 59 per cent of parents and guardians of those aged 6 to 17 in the UK were very or rather worried that their child might see sexually or violently explicit images on the Internet, while 46 per cent were very or rather worried that their child could become a victim of online grooming (Table 6). Child grooming is the term used to describe deliberate actions taken by an adult to form a trusting relationship with a child, with the intent of later having sexual contact. Parents or guardians were also very or rather worried that their child might get information about self-harm, suicide, anorexia (42 per cent) or might become isolated from other people if spending too much time online (41 per cent).

Children also use social networking sites. According to Ofcom, in 200931 per cent of children aged 8 to 11 in the UK and 69 per cent of those aged 12 to 15, used the Internet at home for social networking at least once a week. One in four (25 per cent), Internet users aged 8 to 12 had a page or profile on Facebook, Bebo or MySpace, despite the fact that the minimum age for setting up a profile on these social networking sites is 13 years (Ofcom, 2010c).

According to the National Letter Writing Day report produced by World Vision, more children aged 7 to 14 in the UK are communicating via the social networking site, Facebook, or by e-mail than using more traditional methods such as handwritten letters. In 2010, 49 per cent of children had written an email or a message on Facebook in the week prior to being interviewed, compared with only 14 per cent who had written a handwritten letter in the same period. Likewise, 52 per cent received a message on Facebook or email compared with 9 per cent who had received a handwritten letter (World Vision, 2010). 


\section{New technology in education and work}

New technology has had an impact on education, training and the labour market. Children use computers and the Internet at school and at home for educational purposes as do adults for training, while computers and the Internet are becoming commonplace in the workplace. The use of new technology also allows people to find jobs online and to be able to work from their home.

\section{Figure $8 \quad$ Use of Internet for schoolwork or homework, ${ }^{1} 2009$}

\section{United Kingdom}

Percentages

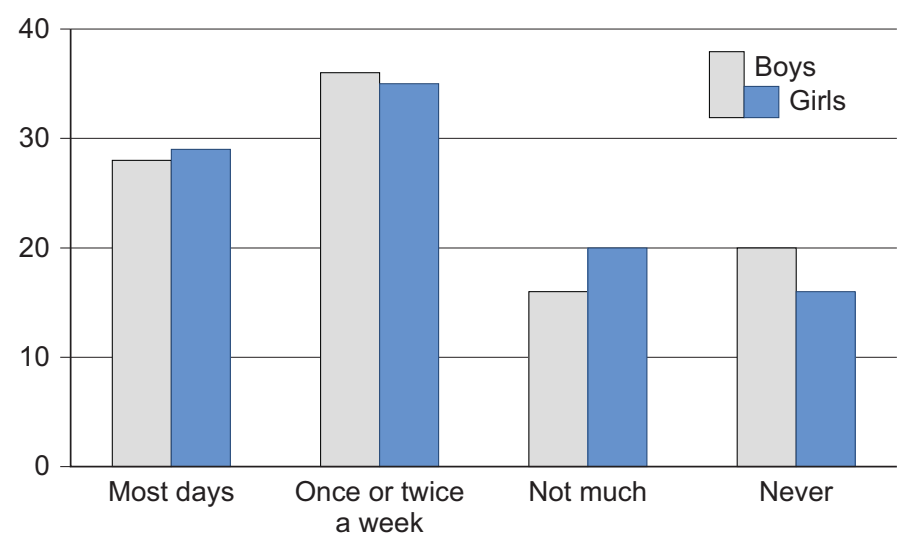

1 Children aged between 5 and 15 who use the Internet at home were asked how often they used the internet for schoolwork and homework and were given the above responses to choose from.

Source: Media Literacy Tracker 2009 (Ofcom, 2010d)

In 2009, similar proportions of boys and girls in the UK aged between 5 and 15 used the Internet on 'most days' (28 and 29 per cent respectively), or once or twice a week (36 and 35 per cent) for schoolwork or homework (Figure 8). More boys than girls never used the Internet for this purpose 20 per cent of boys compared with 16 per cent of girls.

Using the Internet for school or homework increases with age. Among 12 to 15-year-olds, 45 per cent used the Internet for school or homework most days. This proportion dropped to 23 per cent for 8 to 11 -year-olds, and to just 10 per cent for 5 to 7 -year-olds (Ofcom, 2010d). 


\begin{tabular}{lrrrr}
$\begin{array}{l}\text { Table } 7 \\
\text { United Kingdom }\end{array}$ & \multicolumn{2}{l}{$\begin{array}{l}\text { Children's trust in internet content for schoolwork or } \\
\text { homework, 2009 }\end{array}$} \\
\hline & \multicolumn{2}{c}{ Boys } & & Gercentages \\
\cline { 2 - 5 } & Aged 8-11 & Aged 12-15 & Aged 8-11 & Aged 12-15 \\
\cline { 2 - 5 } & 42 & 37 & 37 & 36 \\
All is true & 41 & 52 & 46 & 49 \\
Most is true & 11 & 8 & 9 & 12 \\
Some is true & 6 & 3 & 8 & 4 \\
Don't know & & 37 &
\end{tabular}

1 Children aged between 8 and 15 who use the internet to visit sites for schoolwork or homework were asked 'Do you believe that all of the information you see is true, most of it is true or just some of it is true?'

Source: Media Literacy Tracker 2009 (Ofcom, 2010d)

Trust in Internet content varies by age and gender. In 200939 per cent of pupils aged 8 to 11 and 36 per cent of those aged 12 to 15 in the UK believed that all of the information they see on the Internet for schoolwork or homework is true (Ofcom, 2010d). Forty-four per cent of 8 to 11-year-olds believed that 'most is true' compared with 51 per cent of children aged 12 to 15.

Just over 4 in 10 (42 per cent) of boys and under 4 in 10 (37 per cent) girls aged 8 to 11 believed that all of the information they see on the Internet for homework or schoolwork is true (Table 7). The percentage of boys believing this dropped to 37 per cent at age 12 to 15 while the percentage of girls aged 12 to 15 remained fairly stable at 36 per cent. Just over 4 in 10 (41 per cent) of boys and 46 per cent of girls aged between 8 and 11 believed that of the information seen on the Internet, 'most is true'. Around half of both boys and girls aged 12 to 15 stated that most of the Internet content used for schoolwork and homework was mostly true (52 per cent and 49 per cent respectively).

The number of users of computers with Internet access in the workplace in the UK increased by 27 per cent between 2004 and 2008, from the equivalent to 5.9 million employees in 2004 to 7.5 million in 2008. The largest increase over the period was for businesses employing over 1,000 staff at 36 per cent, from 2.2 million in 2004 to 3.0 million in 2008. This was followed by businesses employing between 10 and 49 employees, from 1.3 million to 1.7 million, a 31 per cent increase. Those employing between 50 and 249, and 250 and 999, employees increased by 23 per cent (1.3 to 1.6 million), and 18 per cent (1.1 to 1.3 million) respectively (ONS, 2008).

Between 2004 and 2008 there was also an increase in the proportion of workers using computers with Internet access as a proportion of all workers using computers. Firms employing between 10 and 49 staff saw an increase of around 8 percentage points (81.3 per cent to 89.5 per cent) over the period. However, companies employing larger numbers of staff increased only slightly, by 0.5 percentage points (71.0 per cent to 71.4 per cent) for those with over 1,000 staff and around 3 percentage points (78.6 per cent to 81.3 per cent) for those employing between 250 and 999 staff (ONS, 2008). 


\section{Figure $9 \quad$ Teleworkers $^{1}$ by region, $2009^{2}$}

United Kingdom

Percentages

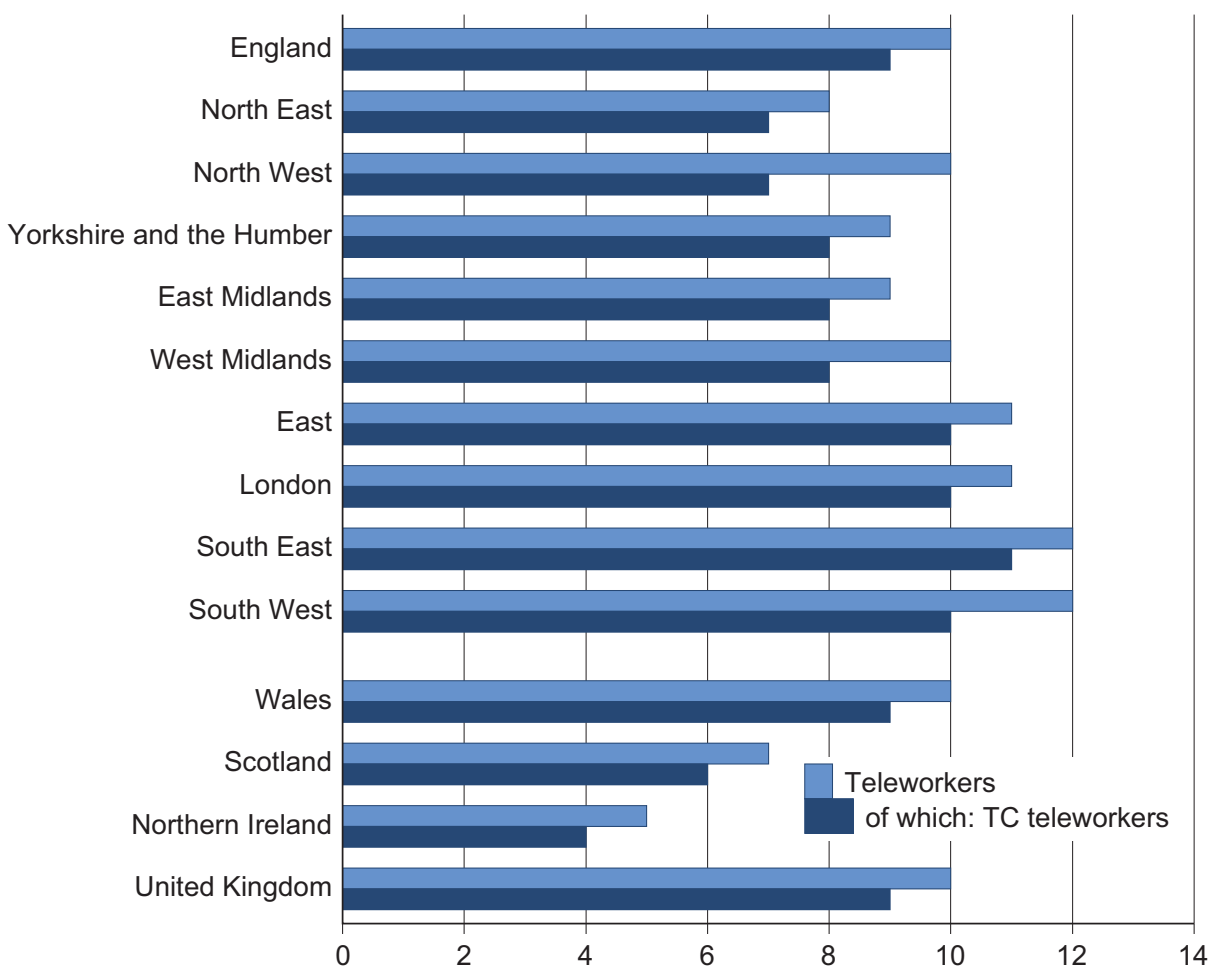

1 Teleworkers are defined in the Labour Force Survey as those people who work mainly at home or mainly in different places using home as a base, who use both a telephone and a computer to carry out their work at home. TC Teleworkers are a subgroup of Teleworkers who could not work at home (or use home as a base) without using both a telephone and computer. Proportion of all in employment.

2 Data are at Q2 (April-June), are not seasonally adjusted.

Source: Labour Force Survey, Office for National Statistics

In England, the Government Office Regions with the highest proportion of teleworkers in 2009 were the South East and South West, both at 12 per cent of all those in employment (Figure 9). These regions were closely followed by London and the East at 11 per cent. The region with the lowest proportion of teleworkers was the North East at 8 per cent. This compares with the UK, England and Wales averages each at 10 per cent. Northern Ireland had the lowest rate of the countries of the UK at 5 per cent.

The English region with the highest percentage who couldn't work at home without both a telephone and a computer (TC teleworkers) was the South East at 11 per cent of all in employment. The North East and North West had the lowest rates at 7 per cent each. The UK, Wales and England averages for TC teleworkers were each 9 per cent, with Scotland at 6 per cent. Northern Ireland also had the lowest rate for TC teleworkers at 4 per cent.

\section{e-Commerce and online banking}

e-Commerce is the buying and selling of products or services over electronic systems such as the Internet and other computer networks. According to the ONS experimental Internet sales series, the value of Internet retail sales in Great Britain increased from an average weekly value of $£ 169.3$ 
million in November 2006 to $£ 446.1$ million in July 2010. In July 2010 the value of Internet retail sales was 8.0 per cent of total retail sales.

\section{Table $8 \quad$ Buying or ordering goods or services over the Internet: ${ }^{1}$ EU-27 comparison}

\begin{tabular}{|c|c|c|c|c|c|c|c|c|c|}
\hline & & & & & & & & & tages \\
\hline & 2006 & 2007 & 2008 & 2009 & & 2006 & 2007 & 2008 & 2009 \\
\hline United Kingdom & 45 & 53 & 57 & 66 & Spain & 15 & 18 & 20 & 23 \\
\hline Denmark & 55 & 56 & 59 & 64 & Poland & 12 & 16 & 18 & 23 \\
\hline Netherlands & 48 & 55 & 56 & 63 & Latvia & 8 & 11 & 16 & 19 \\
\hline Sweden & 55 & 53 & 53 & 63 & Estonia & 7 & 9 & 10 & 17 \\
\hline Luxembourg & 44 & 47 & 49 & 58 & Cyprus & 7 & 10 & 9 & 16 \\
\hline Germany & 49 & 52 & 53 & 56 & Hungary & 7 & 11 & 14 & 16 \\
\hline Finland & 44 & 48 & 51 & 54 & Portugal & 7 & 9 & 10 & 13 \\
\hline France & 22 & 35 & 40 & 45 & Italy & 9 & 10 & 11 & 12 \\
\hline Austria & 32 & 36 & 37 & 41 & Greece & 5 & 8 & 9 & 10 \\
\hline Ireland & 28 & 33 & : & 37 & Lithuania & 4 & 6 & 6 & 8 \\
\hline Belgium & 19 & 21 & 21 & 36 & Bulgaria & 2 & 3 & 3 & 5 \\
\hline Malta & 14 & 20 & 22 & 34 & Romania & 1 & 3 & 4 & 2 \\
\hline Slovakia & 11 & 16 & 23 & 28 & & & & & \\
\hline Czech Republic & 13 & 17 & 23 & 24 & EU-27 average & 26 & 30 & 32 & 37 \\
\hline Slovenia & 13 & 16 & 18 & 24 & & & & & \\
\hline
\end{tabular}

1 People aged 16 to 74 , buying or ordering goods or services for private use over the Internet in the 12 months prior to interview.

Source: Eurostat (table isoc_ec_ibuy)

Among EU-27 member states the use of the Internet to order goods and services was most common in the UK: in 2009, 66 per cent of adults aged 16 to 74 in the UK had done so in the 12 months prior to interview (Table 8). Denmark had the second highest proportion at 64 per cent followed by the Netherlands with 63 per cent. Seventeen countries fell below the EU-27 average of 37 per cent in 2009 with Lithuania, Bulgaria and Romania having the lowest proportions with 8 per cent, 5 per cent and 2 per cent respectively (see Table 1 for proportion of households with Internet access in these countries). All member states recorded increases in the use of the Internet for these purposes between 2006 and 2009, but the increase for France was the greatest at 23 percentage points.

While the majority of Internet users in the EU-27 are confident that transactions over the Internet are completely or rather safe (58 per cent), there is a minority of users who do not have confidence in online transactions. According to a 2008 Flash Eurobarometer report, just over 1 in 10 (11 per cent) 
Internet users in the EU held the opinion that such transactions are not safe at all and just under 2 in 10 (19 per cent) believed that they were not really safe. These proportion were slightly lower in the UK with 5 per cent of Internet users stating that such transaction are not safe at all and 11 per cent stating they were not really safe (Eurobarometer, 2009).

\section{Table $9 \quad$ Adults who used Internet banking: ${ }^{1}$ EU-27 comparison}

\begin{tabular}{|c|c|c|c|c|c|c|c|c|c|}
\hline & & & & & & & & & tages \\
\hline & 2006 & 2007 & 2008 & 2009 & & 2006 & 2007 & 2008 & 2009 \\
\hline Estonia & 79 & 83 & 84 & 87 & Spain & 32 & 31 & 35 & 39 \\
\hline Finland & 81 & 84 & 87 & 87 & Slovenia & 32 & 36 & 38 & 39 \\
\hline Netherlands & 73 & 77 & 79 & 82 & Poland & 23 & 29 & 35 & 38 \\
\hline Sweden & 66 & 71 & 73 & 79 & Slovakia & 25 & 27 & 37 & 38 \\
\hline Denmark & 69 & 70 & 73 & 77 & Portugal & 27 & 29 & 32 & 37 \\
\hline Latvia & 44 & 50 & 64 & 66 & Italy & 25 & 31 & 32 & 34 \\
\hline Belgium & 46 & 52 & 57 & 62 & Cyprus & 18 & 31 & 30 & 32 \\
\hline Luxembourg & 58 & 58 & 60 & 62 & Czech Republic & 22 & 24 & 25 & 31 \\
\hline France & 39 & 51 & 59 & 60 & Hungary & 18 & 23 & 23 & 27 \\
\hline Lithuania & 35 & 43 & 51 & 56 & Greece & 9 & 12 & 13 & 13 \\
\hline Malta & 42 & 48 & 52 & 56 & Romania & 3 & 7 & 7 & 7 \\
\hline United Kingdom & 42 & 45 & 49 & 55 & Bulgaria & 6 & 5 & 4 & 4 \\
\hline Germany & 46 & 49 & 51 & 53 & & & & & \\
\hline Austria & 44 & 44 & 47 & 48 & EU-27 average & 40 & 44 & 47 & 50 \\
\hline Ireland & 40 & 42 & : & 46 & & & & & \\
\hline
\end{tabular}

1 Individuals aged 16 to 74 who had used the Internet in the last three months who had used the Internet for given activity within the three months prior to survey.

Source: Eurostat (table isoc ci i)

Apart from ordering goods and services online, the Internet can be used for other financial transactions such as Internet banking. Among EU-27 member states in 2009 Estonia and Finland had the highest proportions of adults aged 16 to 74 who had used the Internet in the three months prior to interview for Internet Banking both at 87 per cent (Table 9). Over half of adults (55 per cent) in the UK have used Internet banking, a rise of 6 percentage points compared with 2008 and 5 percentage points higher than the EU-27 average of 50 per cent. Bulgaria and Romania had the lowest proportions at 4 per cent and 7 per cent respectively. Since 2006, Latvia has shown the largest growth (22 percentage points) in the proportion of adults using Internet banking, rising from 44 per cent in 2006 to 66 per cent in 2009. In comparison the use of Internet banking in the UK rose by 13 percentage points over the same period. 
Losses through online banking fraud largely due to malware ${ }^{\mathrm{vi}}$ which targets vulnerabilities in customers' PCs, rather than the banks' own systems totalled $£ 59.7$ million in the UK in 2009. These losses have risen from $£ 12.2$ million in 2004, increasing each year except between 2006 and 2007 when they fell from $£ 33.5$ million to $£ 22.6$ million. There were also more than 51,000 phishing incidents recorded during 2009, a 16 per cent increase on the amount seen in 2008 (UK Cards, 2010).

\section{e-Government}

Information and communication technology (ICT) allows citizens to access public services through media such as the Internet at times and in ways that suit them. An increasing amount of national and local government services are now available on the Internet.

According to the ONS Opinions Survey, 46 per cent of adults aged 16 and over in the UK who had accessed the Internet in the 12 months prior to interview had obtained information from a public authority website in 2010. Just over 3 in 10 (31 per cent) had downloaded official forms while under 3 in 10 (27 per cent) had sent filled in forms over the Internet electronically. Men tended to use online public services more than women. Just under half (49 per cent) of men UK who had accessed the Internet in the 12 months prior to interview had obtained information from government websites compared with 43 per cent of women, while a third (33 per cent) had downloaded official forms compared with 28 per cent of women. 


\section{Table $10 \quad$ Online availability of public services: EU-27 comparison ${ }^{1}$}

\begin{tabular}{|c|c|c|c|c|c|c|c|}
\hline & & & & & & & ttages \\
\hline & 2006 & 2007 & 2009 & & 2006 & 2007 & 2009 \\
\hline Austria & 83 & 100 & 100 & Italy & 58 & 70 & 70 \\
\hline Malta & 75 & 95 & 100 & Luxembourg & 25 & 40 & 68 \\
\hline Portugal & 60 & 90 & 100 & Latvia & 10 & 30 & 65 \\
\hline United Kingdom & 71 & 89 & 100 & Hungary & 50 & 50 & 63 \\
\hline Slovenia & 65 & 90 & 95 & Czech Republic & 30 & 55 & 60 \\
\hline Sweden & 74 & 75 & 95 & Lithuania & 40 & 35 & 60 \\
\hline Estonia & 79 & 70 & 90 & Slovakia & 20 & 35 & 55 \\
\hline Finland & 61 & 67 & 89 & Poland & 20 & 25 & 53 \\
\hline Denmark & 63 & 63 & 84 & Cyprus & 35 & 45 & 50 \\
\hline Ireland & 50 & 50 & 83 & Greece & 30 & 45 & 45 \\
\hline Spain & 55 & 70 & 80 & Romania & . & 35 & 45 \\
\hline France & 65 & 70 & 80 & Bulgaria & . & 15 & 40 \\
\hline Netherlands & 53 & 63 & 79 & & & & \\
\hline Germany & 47 & 74 & 74 & EU27 & . & 59 & 74 \\
\hline Belgium & 47 & 60 & 70 & & & & \\
\hline
\end{tabular}

1 Percentage of online availability of 20 basic public services. The indicator shows the percentage of the 20 basic services which are fully available online that is for which it is possible to carry out full electronic case handling. For example if in a country 13 of the 20 services were measured as being 100 per cent available on-line and one service was not relevant (for example does not exist), the indicator is $13 / 19$ which is 68.4 per cent. Measurement is based on a sample of URLs of public web sites agreed with Member States as relevant for each service.

Source: EuroStat (table tsiir120)

In 2009 out of 20 basic public services (12 for citizen and 8 business services) 74 per cent were available online on average across the EU-27 member states, an increase from 59 per cent in 2007 (Table 10). Citizen services included car registration and library services, while business services included environment-related permits and public procurement. In 2009 this online availability measure varied from 100 per cent in Austria, Malta, Portugal and the UK, while Bulgaria had the lowest online availability at 40 per cent. The growth of online public service provision also varied from country to country with some countries recording large increases between 2006 and 2009, such as Latvia (55 percentage points), Luxembourg (43 percentage points) and Portugal (40 percentage points). Public service online availability in the UK increased by 29 percentage points between 2006 and 2009.

Directgov is the UK government's website for citizens of England and Wales, providing a single point of access to public sector information and services. The site enables people to complete tasks online such as booking a driving test, finding a job, paying road tax and finding local services such as NHS clinics and nurseries. There is a similar site for Northern Ireland (nidirect). 


\section{Figure 10 Number of visits to Direct.gov ${ }^{1}$}

United Kingdom

Millions

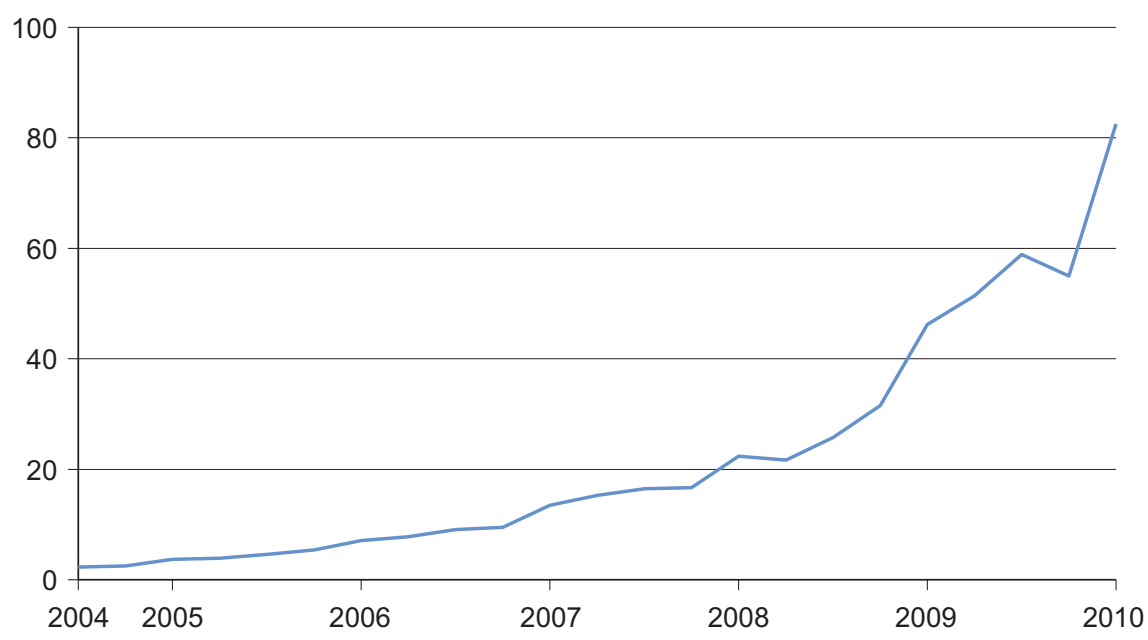

1 Data are at July to December for 2004 and January to March for 2010.

Source: Direct.gov

According to data from Directgov, the number of visits to the Directgov website has increased since it began from 2.3 million in Q3 2004 to 82.5 million in Q1 2010 (Figure 10). In 2009 the site received an average (mean) of almost 52.9 million visits per quarter. Directgov offers information on a number of services in the UK. In 2009 the three most visited were motoring (35.1 million visits), money, tax and benefits (20.8 million visits), and education and learning (17.3 million visits).

Around half of the 70 million motoring transactions carried out each year where users have a choice of channel to use take place using the Department for Transport's electronic and online services. There was a steady increase in the proportion of candidates booking their theory and practical driving tests electronically in the UK between March 2007 and March 2009. In March 2009, just over four-fifths (82 per cent) of theory tests (around 1.4 million) were booked online or electronically, compared with 69 per cent in March 2007. Just under three-quarters (73 per cent) of practical tests (around 1.6 million) were booked online or electronically in March 2009 compared with 59 per cent in March 2007. Candidates can also change the date of their booked practical test online if they need to. More than half (54 per cent) were amended this way in March 2009 (DfT, 2009).

Renewing car tax or making a Statutory Off-Road Notification (SORN) through the Electronic Vehicle Licensing (EVL) system enables customers to complete a transaction either online or over the telephone. According to the Department for Transport, around 17 million of 45 million car tax renewals were carried out this way in 2008/09, a rise of 3 million from 2007/08 (DfT, 2009). 


\section{Figure 11 Her Majesty's Revenue and Customs online returns}

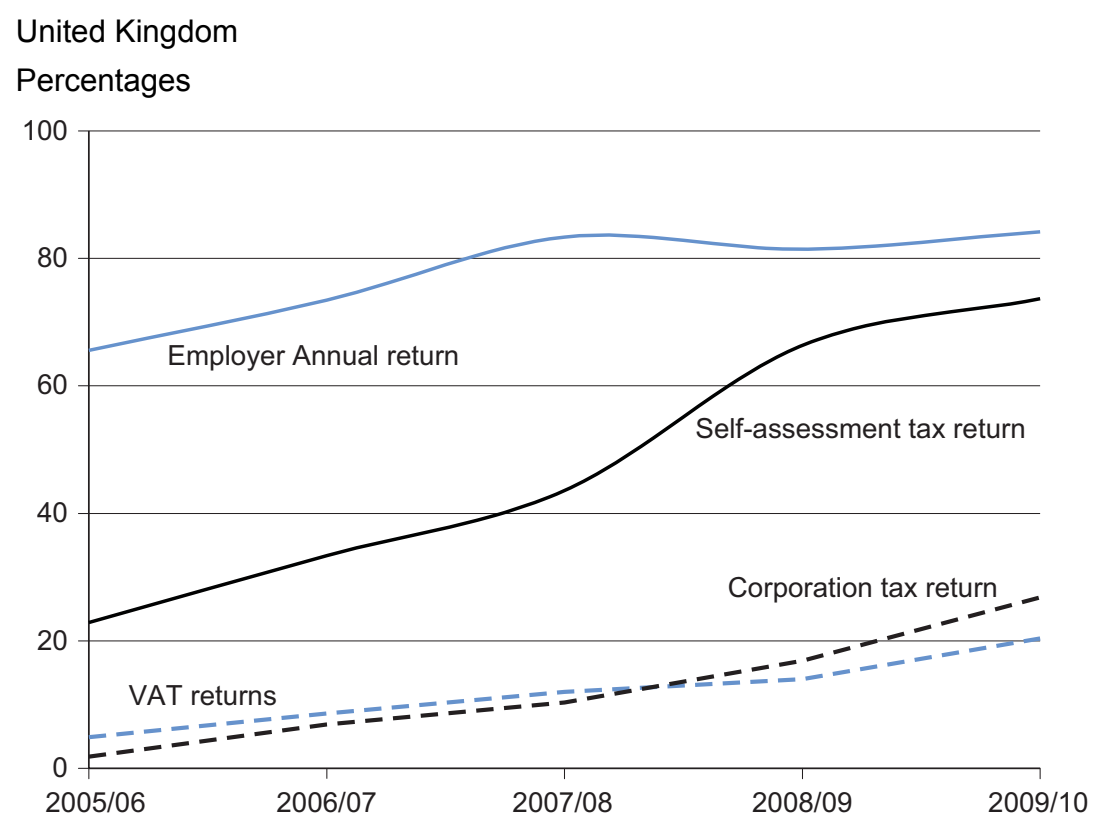

Source: HM Revenue and Customs

Her Majesty's Revenue and Customs (HMRC) is primarily responsible for the collection of taxes and the payment of some forms of state support. In 2006 Lord Carter of Coles report 'Review of HMRC online services', recommended that HMRC should aim for universal electronic delivery of tax returns by 2012 (Carter, 2006). Although it is not compulsory to file Self-Assessment tax returns online, in 2009/10, 74 per cent (6.6 million) were filed online, an increase of 51 percentage points from 2005/06 when 23 per cent (2.0 million) were filed online (Figure 11).

All employers who use Pay as You Earn (PAYE) to deduct their employee's income tax are required to submit the Employer Annual Return (P35) form to HMRC. This form summarises the end of year payroll totals of these deductions for all their employees combined. Since 2006, all employers with 50 or more employees were required to file their returns online and since April 2010 all employers, other than those with a legitimate exemption, are required to file this form online. This has resulted in an increase in online filing of P35s from just under two-thirds (66 per cent) in 2005/06, equivalent to 1.1 million returns, to 84 per cent in 2009/10, a rise of 19 percentage points. From April 2009 all employers with 50 or more employees have been required to send their starter and leaver information online (forms P45, P46 etc.) and from April 2011 all employers will be required to send these forms online too.

There has been an online filing service for VAT returns for several years, but until very recently the extent of customer usage was comparatively low, at less than 20 per cent of all returns received. However, as from 1 April 2010, it was made compulsory for the following customers to file their returns online and pay any VAT due electronically:

- all existing customers whose turnover was $£ 100,000$ or more (excluding VAT) - which accounts for about 1.1 million customers (out of the 1.9 million customer base)

- all new customers registering for VAT on or after that date 
Since the vast majority of VAT customers file on a quarterly basis, that meant that the first set of compulsory online returns were due in by 7 August 2010 (covering the period April - June). Just over 71 per cent of the returns received from 8 July to 7 August were filed online. Additionally, registrations for VAT online services (the first step to being able to file online) reached nearly 1.4 million (an increase of about one million on the same date last year), indicating that in excess of 250,000 customers with a turnover of under $£ 100,000$ for whom it is not compulsory to make online returns have also converted to online filing.

The Internet has made health information more easily available and accessible. Many organisations in the UK provide health information on the web including NHS Choices, NHS Direct, BBC Health and the private healthcare provider, BUPA. From October 2008 the Health A to Z section of NHS Direct online services was integrated with NHS Choices, which acts as a digital gateway and public front to the NHS, providing a one-stop shop for health and social care.

\section{Table 11 Using Internet to find health information, $2009^{1}$}

\begin{tabular}{|c|c|c|c|c|c|}
\hline & $\begin{array}{r}\text { Have } \\
\text { already } \\
\text { done so }\end{array}$ & $\begin{array}{r}\text { Very or } \\
\text { fairly likely }\end{array}$ & $\begin{array}{r}\text { Nether } \\
\text { likely nor } \\
\text { unlikely }\end{array}$ & $\begin{array}{r}\text { Very or } \\
\text { fairly } \\
\text { unlikely }\end{array}$ & $\begin{array}{l}\text { Would not } \\
\text { look for this } \\
\text { information } \\
\text { on the } \\
\text { Internet }\end{array}$ \\
\hline $\begin{array}{l}\text { To help better manage an existing health condition for } \\
\text { myself or a family member }\end{array}$ & 8 & 36 & 9 & 25 & 22 \\
\hline $\begin{array}{l}\text { To check symptoms to determine if I, or a family } \\
\text { member, need to go to the GP or } A \& E\end{array}$ & 8 & 30 & 8 & 30 & 24 \\
\hline To help me choose between different treatment options & 5 & 30 & 9 & 32 & 24 \\
\hline $\begin{array}{l}\text { To find out which vaccines I, or a family member, need } \\
\text { to get }\end{array}$ & 4 & 28 & 9 & 33 & 26 \\
\hline $\begin{array}{l}\text { To find out if I, or my family, have a high risk of } \\
\text { developing a condition and should be tested for it }\end{array}$ & 3 & 29 & 9 & 34 & 25 \\
\hline To find out about healthier lifestyle changes ${ }^{2}$ & 5 & 26 & 9 & 34 & 25 \\
\hline To help me choose a hospital or other health service & 3 & 23 & 10 & 39 & 25 \\
\hline
\end{tabular}

1 Respondents were asked, ' How likely are you to use Internet to find information in each of the following situations'?

2. For example quitting smoking or losing weight.

Source: NHS Choices; TNS CAPI, Public Omnibus Survey

The NHS Choices Public Omnibus Survey 2009 found over half (52 per cent) of people aged 16 or over in England had used the Internet to look up health information generally. This survey also asked people how likely they were to use the Internet to find information for selected health related situations. Fairly small proportions had already used the Internet to find health information, but much higher proportions said that they were very or fairly likely to do so in the future (Table 11). Eight per cent of adults aged 16 and over in England stated they had already used the Internet to check symptoms to determine if they or a family member need to go to a GP or A \& E, with 30 per cent stating they were very or fairly likely to use it for this purpose. Choosing a hospital or other health service was the least common health related situation for which people said they would use the 
Internet, with 3 per cent already having done so and 23 per cent very or fairly likely to do so. A similar proportion of people (22 per cent to 26 per cent) would not look for information on the Internet relating to health related situations that are shown in Table 11. 


\section{References}

Carter, 2006 - Review of HMRC Online Services. Available at www.hmrc.gov.uk/budget2006/carterreview.htm

DfT, 2009 Annual Report and Resource Accounts 2008-09. Available at www.dft.gov.uk/about/publications/apr/ar2009/arra.pdf

Dutton, W., Helsper, E., and Gerber,M. (2009) The Internet in Britain: 2009. Oxford Internet Institute, University of Oxford.

Eurobarometer 2009, Confidence in Information Society. Available at www.ec.europa.eu/public_opinion/flash/fl_250_en.pdf

European Commission (2008. Towards a safer use of the Internet for children in the EU - a parents' perspective: Summary. Available at www.ec.europa.eu/public_opinion/archives/flash_arch_254_240_en.htm

Ofcom (2009a), Accessing the Internet at home: A quantitative and qualitative study among people without the Internet at home by Ipsos Mori. Available at www.stakeholders.ofcom.org.uk/binaries/research/telecomsresearch/bbathome.pdf

Ofcom (2009b), CMR 2009: Nations and Regions - Convergence. Available at www.stakeholders.ofcom.org.uk/binaries/research/cmr/converge1.pdf

Ofcom (2009c) the Communications Market Report: United Kingdom, 2009. Available at www.stakeholders.ofcom.org.uk/market-data-research/market-data/communications-marketreports/cmr09/

Ofcom (2010a), the Communications Market Report: United Kingdom, 2010. Available at www.stakeholders.ofcom.org.uk/market-data-research/market-data/communications-marketreports/cmr10/uk/

Ofcom (2010b). UK adults' media literacy. Available at www.stakeholders.ofcom.org.uk/binaries/research/media-literacy/adults-media-literacy.pdf

Ofcom (2010c). UK children's media literacy. Available at www.stakeholders.ofcom.org.uk/binaries/research/media-literacy/ukchildrensml1.pdf

Ofcom (2010d). Ofcom Media Literacy Tracker 2009 consolidated. Available at www.stakeholders.ofcom.org.uk/binaries/research/statistics/mlt_chlidren.pdf

ONS (2006), Internet access, households and individuals 2006 - First release, available at www.statistics.gov.uk/pdfdir/inta0806.pdf

ONS (2007) Focus on the Digital Age - available at www.statistics.gov.uk/StatBase/Product.asp?vInk=14797\&Pos=4\&ColRank=1\&Rank=144 
ONS (2008) 2008 e-commerce Survey of Business datasets. Available at www.statistics.gov.uk/downloads/theme_economy/ecommerce-2008/2008-datasets.pdf

ONS (2009a). Internet access households and individuals 2009 - Statistical bulletin. Available at www.statistics.gov.uk/pdfdir/iahi0809.pdf

ONS (2009b). Family Spending 2009. Available at www.statistics.gov.uk/statbase/product.asp?vlnk=361

ONS (2010). Internet access households and individuals 2010 - Statistical bulletin. Available at www.statistics.gov.uk/StatBase/Product.asp?vlnk=5672

UK Cards, 2010, Banking Fraud Figures Available at www.cardwatch.org.uk/images/uploads/Fraud\%20Figures\%20Release $\% 2010 \% 20$ Mar\%2010.pdf?Title $=\operatorname{Pr}$ essReleases

World Vision 2010, National Letter Writing Day Available at www.worldvision.org.uk/server.php?show=nav.3585 


\section{Notes}

${ }^{i}$ A dependent child is defined as a person aged 15 and under in a household or aged 16 to 17 in full-time education and who is not married.

ii Narrowband: the computer uses the telephone line to dial up for an Internet connection. Because narrowband access uses normal telephone land lines, the quality of the connection can vary and data rates are limited. A narrowband user cannot be online and use the telephone at the same time.

Broadband provides faster data transferral. High-speed Internet connectivity is provided by Digital Subscriber Line (DSL), cable, satellite and wireless service providers. This means that moving from one web-page to another or downloading large amounts of information, such as software, music or games, takes less time. It is also useful when the user has a particular need for quick communication or is engaged in real-time communication, for example, using web-radio or a chat room connection. A broadband connection allows users to use the telephone while online.

iii Examples of digital convergence include:

- A mobile handset can receive voice calls, data, pictures, audio, video and text, all over a 2G/3G network

- Audio-visual content can be accessed using satellite, cable, digital terrestrial and analogue terrestrial platforms, as well as through a fixed broadband connection or over a mobile network

${ }^{\text {iv }}$ Phishing: the practice of sending emails at random, pretending to come from a genuine company, and attempting to trick users into disclosing information.

${ }^{v}$ Flash Eurobarometers are ad hoc thematical telephone interviews conducted at the request of any service of the European Commission. Flash surveys enable the Commission to obtain results relatively quickly and to focus on specific target groups, as and when required.

${ }^{v i}$ Malware: malicious software, which includes computer viruses that are installed on a computer without the user's knowledge, typically by users clicking on a link in an unsolicited email, or by downloading suspicious software. Malware is capable of logging keystrokes thereby capturing passwords and other financial information. 